Rev. Ter. Ocup. Univ. São Paulo, v. 17, n. 3, p. i, set./dez., 2006.

\title{
Editorial
}

\section{A Rede Nacional de Ensino de Terapia Ocupacional (RENETO)}

\author{
Elisabete Ferreira Mângia ${ }^{1}$, Marta Carvalho de Almeida ${ }^{2}$
}

Em 29 de setembro de 2005, durante o IX Congresso Brasileiro de Terapia Ocupacional realizado em Recife-Pernambuco, aconteceu a primeira assembléia geral da Rede Nacional de Ensino de Terapia Ocupacional (RENETO), formalizando, assim, a criação da primeira associação de ensino em Terapia Ocupacional no Brasil. A associação nasceu da vontade dos docentes de terapia ocupacional, que se organizam em fóruns específicos desde 1986, de poder contar com mais um instrumento de ação política que atue decisivamente no cenário da formação profissional, com base nos anseios coletivos .

De acordo com seu estatuto, a RENETO tem como objetivo central atuar no campo do ensino em Terapia Ocupacional, congregando docentes e instituições de ensino, profissionais que atuam na área do ensino, além da Executiva Nacional de estudantes de Terapia Ocupacional.

Como objetivos específicos a RENETO pretende fomentar o debate sobre o ensino em Terapia Ocupacional, contextualizado na Política Nacional de Educação Superior e promover intercâmbios e colaboração com entidades governamentais, e não governamentais, nacionais e internacionais, que atuam no campo do ensino e com profissionais e estudantes da área.

Agora, com a primeira diretoria eleita durante o X Congresso Nacional de Docentes realizado na UFMG em Belo Horizonte em setembro de 2006, a associação entra em uma fase de consolidação, na qual se torna fundamental a adesão e participação dos docentes da área. Dentre as iniciativas foram organizados 5 grupos de trabalho visando distribuir responsabilidades e trabalho entre os membros da atual diretoria. São eles: a) Políticas Públicas, que inclui a participação da RENETO no Fórum Nacional de Educação das Profissões na área da Saúde - FNEPAS; b) Organização de dados sobre o perfil dos alunos e formandos de Terapia Ocupacional, visando a reflexão sobre os desafios atuais do mercado de trabalho; c) Divulgação da Profissão, que pretende ampliar a visibilidade da Terapia Ocupacional na sociedade e nos espaços institucionais; d) Pesquisa, que visa ampliar as articulações com as entidades financiadoras de pesquisa, especialmente a CAPES e o CNPq, e discutir questões ligadas à Pós-Graduação e finalmente e) Regimento RENETO, que espera contribuir para a realização dos ajustes necessários para o processo de formalização da Associação. Esses grupos são abertos à participação de todos os integrantes da RENETO.

É importante lembrar que a RENETO, antes de se tornar uma associação, uma pessoa jurídica, consolidou-se enquanto rede de comunicação entre os docentes do país, propiciando não apenas a troca de informações, mas a agilização e descentralização dos debates fundamentais presentes no campo do ensino. Isso se deu através da criação de um grupo específico ligado à rede mundial de computadores, constituído por pessoas ligadas ao ensino de terapia ocupacional, independentemente de estarem ou não associadas à RENETO. Porém, a atual diretoria da RENETO espera ver crescer tanto o número de associados quanto o número de participantes do grupo de comunicação virtual, também denominado RENETO.

O fortalecimento da entidade, bem como sua capacidade de agir no sentido de implementar decisões coletivamente discutidas e elaboradas, depende da intensificação da participação de todos os docentes.

Para ingressar no grupo virtual RENETO, deve-se acessar http://br.groups.yahoo.com/group/reneto/. E, no caso de haver interesse em se tornar um associado da entidade, é possível comunicar-se com a diretoria através dos endereços eletrônicos disponibilizados no site.

\footnotetext{
${ }^{1}$ Editora da Revista de Terapia Ocupacional da USP. Docente do curso de Terapia Ocupacional da FMUSP. ${ }^{2}$ Presidente da RENETO. Docente do curso de Terapia Ocupacional da FMUSP.
} 